\title{
UNITY THROUGH DIVERSITY: A CASE STUDY OF CHRISLAM IN LAGOS
}

\author{
Marloes Janson
}

The world has no significant binary features ... it is, on the contrary, divided into overlapping, fragmented cultures, hybrid selves, continuously dissolving and emerging social states. (Asad 2003: 15)

During a sermon, Tela Tella - the founder of Nigeria's Chrislam movement Ifeoluwa - proclaimed: 'Moses is Jesus and Jesus is Muhammad; peace be upon all of them - we love them all.' One of his followers, who called himself a 'Chrislamist', told me after the sermon: 'You can't be a Christian without being a Muslim, and you can't be a Muslim without being a Christian.' These powerful statements reflect well the basis of Chrislam, a series of religious movements that emerged in Nigeria's former capital, Lagos, in the 1970s: ${ }^{1}$ the mixing of Christian and Muslim beliefs and practices. In this article I focus on the two most prominent Chrislam movements in Lagos: Ifeoluwa was the first, and Oke Tude is the most popular. In addition to their Yoruba names, the founders and their followers use 'Chrislam' as a concept for self-designation. Despite their inclusive conception of religion, there is surprisingly little interaction between the Chrislam movements. Although Tella accepts both Christianity and Islam and preaches 'unity', he rejects other forms of Chrislam, such as Oke Tude, as 'inauthentic'. Oke Tude's founder, Saka, claims not to know Tella. Somewhat paradoxically, inclusion and exclusion thus work side by side.

Contrary to conventional understandings of Christianity and Islam as mutually exclusive entities, Chrislam considers them to be inclusive. That these movements originated in Nigeria is of course revealing because its inhabitants are strictly divided between Muslims and Christians along a predominantly north-south axis. Although Southern Nigeria is mostly Christian, the Yoruba ethnic group the protagonists in this article - in the south-west is almost evenly divided between Christians and Muslims (Peel 2000). Christian-Muslim conflict has played a role in Nigerian politics since the centralization of the political system in the 1970s (Falola 1998), and it has become increasingly important since the

\footnotetext{
MARLOES JANSON is a reader in West African Anthropology at SOAS, University of London, and was previously a researcher at the Zentrum Moderner Orient (ZMO) in Berlin. Her ethnographic work focuses on religious reform (both Muslim and Christian) in the Gambia and Nigeria. Janson is the book reviews editor of the Journal of Religion in Africa. Her publications include Islam, Youth, and Modernity in the Gambia: the Tablighi Jama at (Cambridge University Press for the International African Institute, 2014). She received a $\mathrm{PhD}$ in cultural anthropology from Leiden University, the Netherlands. Email: mj19@soas.ac.uk

${ }^{1}$ The 1970 s - the years just after the Nigerian Civil War, when the dramatic growth in oil revenues raised hopes for Nigeria's national development - were a time of religious revival, when Pentecostal groups and Islamic reformist groups came into being (Peel 2016: 220-1). A further indication of religious revival was the emergence of Chrislam in Lagos. Despite the relocation of many government institutions to the federal capital of Abuja in 1991, Lagos remains Nigeria's economic and cultural hub.
} 
political liberalization associated with the return to civilian rule in 1999 , when Christians and Muslims competed for access to the state and its resources (Nolte 2013: 456). The typical image of Nigeria promulgated in the Western media is that of a country being torn by religious violence. Religious violence is, however, just one aspect of Christian-Muslim manifold relations in Nigeria. The case of Chrislam demonstrates that Christianity and Islam are broached readily in the religiously plural setting of Lagos.

The typical response of mainstream Christians and Muslims when they heard that I was conducting research on Chrislam was: 'Welcome to Lagos; here everything is possible.' This response needs to be understood within Hackett's (1989: 280-2) characterization of Nigeria in terms of a 'kaleidoscopic array of religious phenomena'. Remarkably, although many mainstream believers were not particularly offended by Chrislam, ${ }^{2}$ my academic audience seemed to have more problems with a phenomenon such as Chrislam. Every time I presented my research data at seminars and conferences, my listeners' primary reaction was laughter. They seemed to feel unsettled, not knowing how to make sense of Chrislam, thereby reducing it to something trivial against the backdrop of the 'world' religions: Christianity and Islam. Being raised in a tradition that perceives religions as mutually exclusive, I must admit that initially I also found myself somewhat uneasy with Chrislam's religious pluralism. ${ }^{3}$ My colleagues' and my own uneasiness with a movement such as Chrislam could be explained by the conventional Abrahamic understanding of religion as an integrated, internally consistent belief system. Although the scholarly emphasis on religion as a bounded system has long been criticized (see, for example, Gellner 1974; Barber 1981; MacGaffey 1983; Ottenberg 1984; Hackett 1989; Kirsch 2004; Lambek 2008; McIntosh 2009), there is still a tendency to study Christianity and Islam as distinct traditions. According to Fabian, this persistent tendency is highly problematic because 'expectations regarding the logical consistency and coherence of belief systems often lead to elegant but potentially misleading descriptions' (1985: 139). My argument in this article is that Chrislam proposes a model to escape mono-religious approaches, and provides an emic perspective on religious mixing beyond the well-trodden paths that take 'syncretism' as a conceptual frame.

Religious movements such as Chrislam are not a new phenomenon in Africa. ${ }^{4}$ Indeed, Turner (1979) considers the encounter or interaction of two different types

\footnotetext{
${ }^{2}$ Most 'mainstream' believers, however, distanced themselves from Chrislam by saying that as self-respecting Christians or pious Muslims they would not take part in Chrislam rituals.

${ }^{3}$ Drawing on MacGaffey (1983: 16), I define religious pluralism as the phenomenon whereby 'two or more collectivities, each characterized by its own set of basic institutions, are differentially incorporated within the same ... framework'. Rather than a 'problem' opposing the neo-Platonic tradition of 'monism', I consider religious pluralism an opportunity to reconsider essentialist notions of 'world' religion and to rethink the coexistence of religious traditions in West Africa today.

${ }^{4}$ Most of the cases described in the literature concern the mixing of African traditional religion with Christianity - and less often with Islam - which are artificially distanced as 'traditional' and 'modern' (MacGaffey 1983: 18), and not so much the fusion of two monotheistic religions. What is distinctly new about the movements described here is their deliberate appropriation of Christian and Muslim elements, as reflected in the name they appropriated for their self-designation: Chrislam.
} 
of religion a necessary cause for the emergence of all religious movements in subSaharan Africa. Succeeding generations of Africanists had more problems with this interaction model, describing what in Turner's terms are new religious movements as syncretic forms of 'African Christianity' or 'African Islam'. Although, due to its fusion of Christian and Muslim elements, it might seem obvious to study Chrislam in terms of syncretism - defined by Stewart (1999: 58) as 'the combination of elements from two or more different religious traditions' - here I argue that this is a misleading appellation. In fact, Chrislam provides a rationale for scrutinizing the very concept of syncretism and offers an alternative analytical case for understanding its mode of religious pluralism. Instead, I propose 'assemblage' as a heuristic device for understanding the religious mixing within Chrislam. Collier and Ong define an assemblage as 'the product of multiple determinations that are not reducible to a single logic ... It does not always involve new forms, but forms that are shifting, in formation, or at stake ... [It is] heterogeneous, contingent, unstable, partial, and situated' (2005: 12). Inspired by Collier and Ong, I will show that assemblage theory may help us understand the emergent, fluid and rhizomatic nature of Chrislam.

Compared with the Nigerian Pentecostal mega-churches such as the Redeemed Christian Church of God (RCCG) and Muslim mass organizations including Nasr Allah al-Fatih Society of Nigeria - which translates as 'There is no help except from Allah' and is abbreviated to NASFAT ${ }^{5}$ - Chrislam is somewhat marginal. Despite its marginality, I study the movement as a symptom of wider religious shifts and transformations that are difficult to map because of the ingrained conception of religion as an internally consistent belief system preoccupied with universal truth. Drawing on Larkin and Meyer (2006), I argue that, rather than taking for granted the oppositions between Christianity and Islam, we must explore the convergence between the two religious traditions, thereby crossing boundaries and blurring sharp distinctions. ${ }^{6}$ According to Larkin and Meyer, new reformist trends in Christianity and Islam in West Africa should be studied as doppelgängers - 'enemies whose actions mirror each other and whose fates are largely intertwined' (2006: 287). ${ }^{7}$ Indeed, despite the conflict of opinions between Christians and Muslims - a conflict that has all too often degenerated

\footnotetext{
${ }^{5}$ NASFAT (which is also known as the Nasrul-Lahi-il Fathi Society of Nigeria) was founded in Lagos in 1995 by a group of young Yoruba professionals who were concerned about the lack of religious awareness among higher-class youth. Targeting Muslim youth, its leadership fashioned NASFAT as a revivalist Muslim movement aspiring to achieve 'conformity with modernity'. Established at a time when the Pentecostal presence in the public sphere was increasingly pronounced, NASFAT is probably the most effective response to Pentecostalism, adopting many practices and strategies from it (Soares 2009; Peel 2016: 186-91; Janson forthcoming).

${ }^{6}$ Larkin and Meyer (2006: 287-8) identify three basic commonalities between Pentecostal Christianity and reformist Islam in West Africa: both religious traditions distance themselves from local religious and cultural traditions; both offer their adherents new ways of becoming 'modern'; and both see themselves as part of global movements.

${ }^{7}$ For the study of Christianity and Islam as mirror images, see also Loimeier (2005), Cooper (2006), Marshall (2009) and Janson (2016). However, as Peel points out in his response (this issue), there are also irreconcilable differences between Christianity and Islam in West Africa, notably in the call for sharia and an Islamic state. Yet, although not taking jihad as their model to bring about religious reform, many current Pentecostal churches dream, more or less openly, about a Christian nation (Marshall 2009; see also Obadare, this issue).
} 
into violence in Nigeria - they actually share a great deal of common ground and, while disagreeing on doctrine, overlap in several of the religious practices on which they depend and the social processes they set in motion. Chrislam provides more insight into the complex process of copying and the dynamism of the entanglements between Christianity and Islam that are touched on by Larkin and Meyer in their seminal article.

Although I do not deny that Christianity and Islam have their own distinctive traditions in Nigeria, my point here is that we should focus more on how people actually 'live' religion and how their ways of 'living' religion relate to each other. By focusing on lived religion, it will become apparent that the idiosyncratic ways in which religion is performed are often marked by contradiction, ambivalence and double standards rather than by neat divisions along religious boundaries (see also Marsden 2005; Schielke and Debevec 2012; Janson 2014; 2016). The challenge is thus to develop a new conceptual framework to explore mutual influences and interactions between Christians and Muslims, and Chrislam may help us in this undertaking.

\section{CHRISTIAN-MUSLIM ENCOUNTERS IN NIGERIA}

Nigeria has a long history of conflict and religious violence (Falola 1998). The country, known as the 'giant of Africa' because, with its approximately 170 million inhabitants, it is Africa's most populous country, is therefore an interesting setting in which to study Chrislam. As Smith (2007: xii) points out, conflict and violence are so closely associated with the image that people (not only outsiders but also Nigerians themselves) have of the country that a common phrase in Pidgin English to characterize the nation is 'Nigeria is a war'. However, Christian-Muslim relations are not just marked by conflict: Christians and Muslims have long lived side by side in Nigeria, often in harmony with 'traditional' practitioners - the boundaries between the three not always sharply demarcated (Peel 2000; 2016). For centuries, there were high levels of social interaction between Christians, Muslims and traditionalists, and interfaith marriages were not uncommon (Soares 2006: 2-3).

Many analysts date the beginning of Christian-Muslim confrontations to $1978,{ }^{8}$ when a new constitution had to be adopted after power temporarily shifted from the military regime to civil politicians. Conflicts arose over the question of whether Nigeria would become a secular state or subscribe to the sharia legal system (Falola 1998: 3). The battle over sharia law paved the way for the violence of the 1980s. The most notable crisis occurred in 1987 in the College of Education in Kafanchan, Kaduna State, when Christians belonging to the Federation of Christian Students organized what they called 'Mission '87 in Jesus Campus', a title they proclaimed with a banner at the entrance to the

\footnotetext{
${ }^{8}$ However, this is not to say that Nigeria was free from religious tension before the 1970 s. For instance, in the nineteenth century, Usman dan Fodio led a jihad that resulted in the creation of the Sokoto Caliphate, the largest state in West Africa until it was conquered by the British. But since the late 1970s, incidents of religious violence have increased in number, spread geographically, and affected larger portions of the population (Falola 1998: 5).
} 
college. The college's Muslim students removed the banner and protested against the talk given by a Muslim convert to Christianity, who allegedly misinterpreted Qur'anic verses and falsified the prophecy of Muhammad. The struggle between Christian and Muslim students led to violence in other urban centres in Northern and Central Nigeria, leaving many dead and churches and mosques destroyed. There have been several other such incidents of Christian-Muslim tension on college campuses over the years (Falola 1998: 179-87).

The economic decline and neoliberal reforms of the 1980s and 1990s made it easier for religious leaders to mobilize followers, thereby contributing to religious polarization. Since 2000, a new field of conflict has been added to the long list of Christian-Muslim clashes: the introduction of sharia law in twelve of the northern states, which instigated Christian anxieties about Nigeria becoming an Islamic state (Loimeier 2007: 65-9). ${ }^{9}$ Christian-Muslim relations have deteriorated further because of the violent attacks against Christians in which Boko Haram is involved. ${ }^{10}$ Initially, this militant Islamist group based in the north-east of Nigeria attacked security forces in particular; the latter symbolized the immorality and corruptness of the secular Nigerian state. Boko Haram changed its policy after the killing of its leader Muhammad Yusuf in 2009. The target then shifted from government representatives and institutions to Christians. The international world was shocked when, on Christmas Eve 2010, Boko Haram insurgents bombed a church in Jos - the ethnic and religious fault line that divides the mainly Muslim North from the largely Christian South. In January 2012, Boko Haram gave a three-day ultimatum to all Christians to leave Northern Nigeria and summoned all Muslims to leave Southern Nigeria. In this way, the militant group aimed to bring about a sharper division of Nigeria into a northern, Muslim bloc and a southern, Christian enclave (Higazi 2013).

Since the late 1970s, a time of great political and economic turmoil, there has been competition, as well as higher levels of radicalization, not only between but also within the different religious traditions. In 1978, the Islamic reformist movement Jama'at Izalat al-Bid'a wa-Iqamat as-Sunna - that is, the Society for the Removal of Innovation and Reinstatement of the Sunna, or Izala for short rose to prominence with a series of attacks against Sufism, the mystic orders that up to that point had effectively dominated Islam in Nigeria (Loimeier 1997;

\footnotetext{
${ }^{9}$ Although the issue of sharia law added to the existing anxieties among Christians about being dominated by Muslims, Loimeier (2007: 59) warns us not to consider sharia as the sole instigator of Christian-Muslim clashes. For example, a considerable number of Christian-Muslim tensions have occurred in Plateau State, where sharia has not been implemented. The conflicts in Plateau State are mostly linked to disputes over land and access to resources between settlers and immigrant groups. This demonstrates that conflict in Nigeria is instrumentalized for a variety of reasons.

${ }^{10}$ The Boko Haram uprising was not the first forceful attempt to impose a religious ideology on a secular Nigerian society. Boko Haram can be compared with Maitatsine in terms of philosophy, objectives and organizational planning (Adesoji 2010: 96-8). The Cameroonian Mohammed Marwa, alias Maitatsine ('the Master of Condemnation'), founded the radical Maitatsine movement in Kano in the 1970s. Marwa's movement was highly controversial: he refused to believe that Muhammad was the Prophet and he claimed to be a prophet himself. Maitatsine was responsible for many riots (envisioned as jihad), during which Christians and churches were attacked, resulting in the deaths of thousands of people. Like Boko Haram, Maitatsine propagated a stricter form of Islamic practice by condemning Western culture.
} 
Kane 2003). In its efforts to reform Nigerian society, Izala fought against a broad range of Sufi practices that it labelled un-Islamic, such as amulets, saint veneration, supererogatory prayers, and conspicuous lifecycle rituals. However, with the growing 'Pentecostalization' of Nigerian society (Marshall 2009) in the 1980s, reformist and Sufi Muslims drew closer to each other. According to Loimeier (1997: 308), the leaders of Izala and the Sufi orders shelved their disputes and formed a 'coalition of convenience' in order to better resist the Christian 'crusade'. While these alliances of convenience have led to a considerable pacification of intra-Muslim disputes, they have facilitated increasing religious polarization between Muslims and Christians (Loimeier 2007: 60-2).

The rapid rise and spread of Pentecostalism and its increased presence in the public sphere have fundamentally altered Nigeria's religious landscape. As Ojo (1988: 179-84) and Peel (2000: 314) point out, the Pentecostal movement did not take off in Nigeria until the 1970s, when vastly increased public revenues from oil permitted a great expansion of higher education and fuelled urban growth. Pentecostalism had its roots among university staff and students. It later moved with them off campus and continued to grow in the urban centres. Due to worsening economic and political conditions as a result of collapsing oil prices in the 1980s, Pentecostalism expanded even faster. By the mid-1990s, the Redeemed Christian Church of God's monthly 'Holy Ghost Nights' had become the largest gathering of any kind ever held in Nigeria, attracting tens of thousands of worshippers.

Over the past decades, Pentecostalism has drawn many Nigerian Christians from the mainline Protestant churches, the Roman Catholic Church and the African Independent or Aladura churches, ${ }^{11}$ promising them spiritual rebirth. The Pentecostal upsurge has thus played a central role in the increasing political cleavage and violence along religious lines. Pentecostals are fighting what they see as 'a life and death battle with the enemy': that is, with Muslims (MarshallFratani 1998: 308). Muslims have reacted with equally aggressive proselytization campaigns. Given the mutual demonizing rhetoric of Christian and Muslim preachers in Nigeria in recent years, their proselytizing has contributed to what Last (2007) has called an 'economy of political panic'.

Here it should be noted that where Christian-Muslim conflicts prevail, it would be better to describe the causes of these conflicts as a mixture of different factors, with religion being only one; many of them are rooted in colonial and postcolonial development (Falola 1998: 12-4; Loimeier 2007: 60). The striking gap between the Christian South and the Muslim North in educational standards and wealth has its roots in British colonial policies. The colonial rulers privileged Christianity and produced a new elite, which controlled the postcolonial economy and bureaucracy (Falola 1998: 38; Nolte 2013: 462). In addition to the uneven access to state facilities and distribution of resources, other factors contributing to inter-religious conflict included the effects of the Civil War (1967-70), the foreclosure of all democratic debate by the military regimes that succeeded one another until 1998, the manipulation of religion to accentuate ethnic differences as a tool to

\footnotetext{
${ }^{11}$ Aladura churches were founded in the early 1930 s with the aim of Africanizing the Protestant mission churches (Peel 1968).
} 
retain political power, and the difficulties of managing plural identities in a federal state system (Falola 1998; Danfulani 2005; Last 2007; Loimeier 2007).

In this current of conflict, the religiously plural south-western part of Nigeria, called 'Yorubaland', is something of an exception. Christians, Muslims and practitioners of 'traditional' or Yoruba religion have lived together relatively harmoniously here since the nineteenth century, making the region an icon of ecumenism (Peel 2000; 2016). Indeed, many extended families in Yorubaland are composed of Christians, Muslims and practitioners of Yoruba religion; and mutual participation in each other's ritual festivities is a standard feature of Yoruba social life. For instance, an elderly Christian told me that during Christmas he asks a Muslim butcher to slaughter a ram for him in the halal way (lawful in Islam), so that his Muslim relatives and neighbours can also partake of the meal. Similarly, Christians take part in the festivities at the end of Ramadan. The family situation of my research assistant Tobi is another example of Yorubaland's multiform religious landscape. Tobi's Muslim father married two wives: the first (Tobi's late mother) was a Muslim while the second is a Christian. Tobi's elder brother is a Muslim scholar who spends his leisure time listening to tape-recorded sermons, while his younger half-brothers, who are DJs and live in the same family house in Lagos, play popular music, and his half-sister, who is a member of a Pentecostal choir, practises her Christian hymns. Tobi married a woman from an Aladura church who converted to Islam upon their marriage. To avoid offending either his family or his in-laws, the wedding took place in a wedding hall instead of a mosque or church. It took Tobi's wife some years to replace the cross around her neck with a veil. Tobi and his wife raise their two daughters as Muslims. To make things more complicated, Tobi goes by his Yoruba instead of his Muslim name so that even those who are close to him cannot immediately tell his religion.

Given its particular religious constellation, it is not surprising that Chrislam originated in Yorubaland. Nor is it surprising that this is the only place where it thrives. According to Laitin, 'Muslim and Christian Yorubas see themselves culturally as Yorubas rather than as Muslims or Christians' (1986: 97). Because Yoruba attach more value to common ethnicity than to religious affiliation, Chrislam can be considered a Yoruba phenomenon: it is the shared ethnicity that makes the mixing between Christianity and Islam possible. Several interlocutors argued that if Chrislam were to have emerged in Hausaland in Northern Nigeria, 'the founders and their followers would have been dead by now, because unlike the Yoruba, northerners are not tolerant'. An exception to the image of northerners as 'fundamentalists' is the Interfaith Mediation Centre (IMC), which was founded by Pastor James Wuye and Imam Muhammad Ashafa Nuruddin in the religious hotbed of Kaduna in 1995. ${ }^{12}$ The centre's mission is to mediate between Christians and Muslims in order to 'create a peaceful society'. ${ }^{13}$ Unlike the IMC's pioneers, the Chrislam founders do not so much situate their movements against the backdrop of religious violence plaguing

\footnotetext{
${ }^{12}$ The IMC's story is featured in the documentary The Imam and the Pastor, produced by FLT Films. A 2010 follow-up documentary, An African Answer, chronicles their journey since then and the reconciliation process approaches in Kenya (<http://www.fltfilms.org.uk/>).

${ }^{13}$ See $<$ http://www.imcnigeria.org $>$.
} 
Nigeria but rather against the unstable flux of life in Lagos (see below). Although they see it as their task to 'bring unity between Christians and Muslims', their movements are not examples of what scholars attempting to advance ecumenical ideas have called 'interfaith dialogue' (for example, Hock 2004). Rather than enabling interfaith dialogue, the Chrislam founders see it as their mission to mix Christian and Muslim rituals in an effort to bring about 'deliverance' in their followers' lives, as expressed through success, wealth and good health. ${ }^{14}$ Here, it should be noted that Chrislam is not represented by the Nigeria Inter-Religious Council (NIREC), which was established with the aim of promoting greater understanding among Nigerian Christians and Muslims in 2000. In an interview, the cochairman of NIREC depicted Chrislam to me as a 'heretic sect' that was unrelated to NIREC's higher aim of 'laying the foundations for religious harmony'.

Yorubaland's cosmopolitan centre is Lagos. This megacity with an estimated population of 20 million represents a crossroads of people and commodities from around the continent and the world. It is a node not only for migrants seeking jobs and education, but also for drug-traffickers, smugglers and fraudsters or ' 419 '. ${ }^{15}$ The amorality that is associated with life in the 'Sin City' (Ukah 2013: 182 ) is compensated by a saturation of both the public sphere and people's private lives with religion. Because religion to a large extent delimits the microprocesses of everyday living in Lagos, Ukah (2013: 179) predicts that it will increasingly influence the future and the trajectory of its transformation into the third largest city in the world in the twenty-first century - according to a United Nations' projection.

It is not easy to describe life in Lagos to those who have never been there. I think Smith's (2007: xii) description that in Lagos 'the volume is turned up - sometimes too high' is striking. Despite several attempts by Lagos Governor Fashola to implement a law that prohibits religious organizations from using loudspeakers at night, Lagos's soundscape is marked by what Larkin (2008) calls 'religious noise'. Lagos's huge population and process of rapid urbanization contribute to a sense of life that is not only loud but also turbulent and hectic, where survival depends on improvisation, risk-taking and ingenuity (see also De Boeck and Plissart 2014). In this environment, religious 'entrepreneurs' consider Chrislam not a contradiction in terms but an example of the resourcefulness of Lagosians, who - as will become clear below - by adopting both Christian and Muslim practices increase their chances of having a better life, if not in the hereafter than at least in this world.

\section{IFEOLUWA: THE WILL OF GOD MISSION}

The oldest Chrislam movement was founded in Lagos in 1976 by a Yoruba man named Tela Tella. In addition to 'Chrislam', he refers to his mission as Ifeoluwa, Yoruba for 'The Love of God Mission'. Similar to Islam, Ifeoluwa is based on five pillars, with 'love' being the first one. The others are 'mercy', 'joy', 'good deeds'

\footnotetext{
${ }^{14}$ Deliverance may be understood broadly as what the Yoruba call Alafia, a condition of wellbeing with health and prosperity as its main components; this sums up what individuals pray for and wish for one another (see also Peel, this issue).

${ }^{15}$ ' 419 ' is what Nigerians call fraud, apparently after a section in the Nigerian criminal code that describes these crimes (Smith 2001: 804).
} 
and 'truth'. Tella sees himself as God's love incarnated in a human being, who has been ordained to 'enlighten the world': 'I'm the will of God personified. The word of God is Jesus. The motor of my mission is love, peace, and abide. My followers abide by the laws, rules, and regulations of Ifeoluwa. I'm an instrument in the hands of God.' According to Tella, God communicates with him via divine revelations, which he conveys through glossolalia. Until the world is ready to receive these revelations, Tella lives a secluded life with his two wives (the Lady Apostles) and their children (the Prayer Warriors) on the 'Mountain of Power': 16 that is, a whitewashed compound in a densely populated slum area in Lagos. On the compound's fenced wall, Ifeoluwa's symbols are portrayed: a wooden slate, with a Christian cross in the middle, on which students learn to write Arabic in traditional Qur'anic schools; and a heart signifying love.

Tella has a small congregation, composed of about fifty lower middle-class followers, that meets every Saturday. Similar to many other religious organizations in Lagos, youth outnumber elders and women outnumber men in the congregation. A young Ifeoluwa member (whose husband is a Muslim who does not attend Ifeoluwa services) explained: 'Men don't care. We women are more concerned about our children, families, and businesses. That's why you find more women in Chrislam - but not only there: in all religious organizations in this country women are over-represented.' Both men and women hold leading positions in Ifeoluwa, but since women are believed to be 'impure', they - like Muslim women - are not allowed to attend services when they are menstruating.

During an interview, Tella explained why his congregation meets on Saturday, and not in a mosque or church but in a temple:

I don't want to lean on Friday since Friday is for the Muslims, and I don't want to lean on Sunday since Sunday is for the Christians. Therefore we congregate on Saturday, which is the Sabbath. ${ }^{17}$ In previous years, services took place on both Fridays and Sundays but because people accused me of practising my faith half-way, I decided to switch to Saturdays ... Ifeoluwa is unique. I don't love Jesus more than the Prophet. I love them all and they love me.

To prevent accusations of favouring Christians above Muslims or vice versa, Tella refused to talk about his religious background. Nevertheless, it is generally known that he was a Muslim before founding Chrislam.

Tella's temple is composed of a garage-like white building with, in the middle, a colourful altar that is separated by a curtain from the prayer ground, where, as in a mosque, the congregation sits on the floor. The Saturday service starts with singing Christian and Muslim songs from the Ifeoluwa 'hymn book' and the Ifeoluwa 'creed':

The God of Jesus is One

The God of Muhammad is One

Humanity is one

Chrislam, Chrislam, Chrislam.

The singing is accompanied by African instruments as well as a Western drum kit.

\footnotetext{
${ }^{16}$ 'Mountain' has a strong reference to Mount Sinai in Egypt, where, according to Christian and Jewish traditions, Moses received the Ten Commandments.

${ }^{17}$ Besides the Sabbath, I did not come across other references to Judaism in Ifeoluwa.
} 
While the singing is going on, Tella enters the temple accompanied by his disciples, who hold burning candles and ring bells with which 'to summon the angels'. Resembling the Muslim practice of tawaf, Tella circumambulates the Holy Spirit Square - an open space decorated with a cross - seven times while holding both a Bible and a Qur'an. ${ }^{18}$ According to Tella, the holy scriptures are incomplete and contain some inaccuracies. For this reason he is working on his own Holy Book, the Ifeoluwa Book, which will be the last book. Since he does not consider himself a religious scholar, the book contains none of his own theologies but only divine revelations. After circumnavigating the Holy Spirit Square, Tella delivers a sermon in Yoruba and English recounting passages from the Bible, Qur'an and Ifeoluwa Book. I heard Tella preaching, elucidating his message of love in a way that recalls the Pentecostal theology of the Prosperity Gospel: ${ }^{19}$

God doesn't love one religion more than another. Among all religions, Christianity and Islam are closest to each other. Christians and Muslims should love each other, but instead they hate each other. Because they don't open their hearts for love, they have problems. God means love. The way to reach God is through love. Once you receive my message of love and disseminate it to others, you will prosper in life. If you want prosperity in your business, radiate love. If you want success in your life, you must spread the gospel of love.

The service ends with a joint prayer mixing Christian and Muslim elements. Unlike Muslims, who pray five times a day, Ifeoluwa's congregation prays only twice a day. Tella explained: 'Life in Lagos is hectic. We don't have time to pray more than twice a day, but we love God constantly in our hearts.' This pragmatic approach to religion is characteristic of Chrislam, as we will see later. The closing prayer, during which Ifeoluwa members gesticulate wildly with their arms to 'open the way for deliverance in their lives', is followed by testimonies and thanksgiving. Similar to Pentecostal services, the testimonies recount the 'miracles' encountered by Tella's followers when they accepted God's love in their lives, including healing, the birth of a baby, finding employment, and a windfall.

In addition to the weekly service, which lasts for about three hours, the congregation assembles every Friday to attend the Holy Ghost service, an all-night prayer meeting. Once a year they set out on a pilgrimage to the 'Mount of Authority' in Tella's home town, where they pray and fast uninterruptedly for three days. Tella's daughter explained: 'Like the Muslims have their pilgrimage centre in Mecca and the Christians in Jerusalem, we have our pilgrimage centre on the Mount of Authority. We are proud that God has chosen Nigeria as Chrislam's pilgrimage centre.' Another annual event is the Dancing Anniversary, when Tella - who is 'like King David commanded by God to

\footnotetext{
${ }^{18}$ Tawaf is one of the Muslim rituals of pilgrimage. During the hajj (pilgrimage to Mecca), Muslims circumambulate the Ka aba (the most sacred site in Islam) seven times. This circling is believed to demonstrate the unity of the believers in the worship of God, as they move in harmony together around the Ka'aba, while supplicating to Allah.

${ }^{19}$ According to the Prosperity Gospel, God bestows spiritual and material blessings on those $\mathrm{He}$ loves, whereas the Devil is responsible for the Spirit of Poverty, which has so many Africans in its grip (Larkin and Meyer 2006: 290-1, note 6).
} 
dance for Him' - dances and brings out the religious paraphernalia that are normally kept inside the temple. This is an important event for the congregation, which receives special blessings on that day.

Somewhat paradoxically, despite Chrislam's inclusive conception of religion, Tella seems to draw upon the idiom of the secret society - a socio-religious institution in Nigerian society that provides collective solidarity and security for its members - as the basis for his mission. ${ }^{20}$ Membership is modelled on an initiation rite and requires years of spiritual training. Initiation is expected to elicit a higher spirituality and new moral lifestyle that will promote social harmony in society. Just as membership in a secret society is constrained by restricted knowledge, membership of Ifeoluwa is restricted by the observance of eighty rules and regulations concerning codes of moral behaviour, dress codes (like Muslim women, Tella's female followers are obliged to cover their heads and to dress modestly), and food taboos derived from the Old Testament. During their spiritual training, the initiates earn different spiritual ranks, symbolized by coloured belts worn on their white gowns, ${ }^{21}$ and religious paraphernalia such as prayer sticks and swords. These religious items are believed to protect them against spiritual attacks by evil forces, and enable them to heal fellow worshippers. In order to reach a higher spiritual level that brings them closer to God, initiates fast on Fridays - the most holy day in the Muslim calendar.

Tella is aware of the fact that Ifeoluwa's strict rules and regulations prevent adherents from committing themselves wholeheartedly. Adherents often attend weekly services and special programmes for some time, but, when the problem that brought them to Ifeoluwa has been resolved, they return to their original church, mosque or shrine. As a result, there is a high level of fluctuation among the congregation. To pierce the cloud of secrecy surrounding himself and his mission and to attract more adherents, Tella has recently joined Facebook. Although this has led to a small increase in worshippers attending Ifeoluwa's services, and a modest international following intrigued by the idea that Chrislam might be the solution to the Israel-Palestine conflict, Tella wants to keep his congregation 'manageable' so that he can rule it as a 'spiritual family': 'The more people, the more wahala ['trouble' in Pidgin English].' Just as his mother was allegedly pregnant with him for thirteen months, he thinks that his mission - which aims to bring 'a new world order beyond the imagination of homo sapiens' - also needs time to flourish.

\section{OKE TUDE: MOUNTAIN OF LOOSING BONDAGE}

Tella had complained that a man calling himself Prophet Dr Samsindeen Saka ${ }^{22}$ had stolen his idea and founded his own Chrislam movement in 1989. Although

\footnotetext{
${ }^{20}$ As Gore and Pratten (2003) point out, during the economic crisis in the mid-1980s, and especially during the coercive and repressive military regimes of the 1990s, secret forms of organization such as the Reformed Ogboni Fraternity re-emerged in Nigeria.

${ }^{21}$ The wearing of white gowns by Ifeoluwa worshippers is a reminder of the dress code in the socalled 'White Garment Churches' (alasofunfun) - that is, Aladura churches - as well as in certain Muslim prayer groups (Peel 1968; 2016: 190).

${ }^{22}$ Based on his power to 'see' ('seeing' is the term used in Pentecostal churches for prophecy), Saka regards himself as a prophet intermediating between God and his followers. Besides
} 
several of his followers advised him to take Saka to court, Tella refused, saying: 'I don't like wahala. God knows the truth.' In addition to Chrislam, Saka's movement is also known by its Yoruba name Oke Tude, 'Mountain of Loosing Bondage', a name that is redolent of Pentecostal discourse. Similar to Pentecostal churches, the basic idea behind Oke Tude is that worshippers' progress in life is blocked by evil powers that hold them trapped in bondage with Satan. These powers are personified as 'witches and wizards' ${ }^{23}$ By fasting and participating in a ritual called Tude or 'running deliverance', during which worshippers run seven times around a replica of the Ka 'aba (the most sacred site in Islam) containing a well with 'holy water' while shouting 'Hallelujah' and 'Allah Akbar' ('God is great'), ${ }^{24}$ it is believed that they can be 'delivered' from these demonic forces. Deliverance, which is accompanied by possession by the Holy Spirit, is expressed through good health. The crutches hanging on the wall next to the well serve as proof of the healing powers of Saka, who even claims to be able to cure AIDS. ${ }^{25}$ Physical healing is but one aspect of deliverance: there are also promises of affluence, fertility, virility, finding a partner, freedom from family problems, passing exams and getting jobs when taking part in Tude. This deliverance ideology explains Oke Tude's popularity in Lagos, especially among socially marginalized groups including barren women and unemployed youth.

In Nigerian society, bearing children is a prerequisite for attaining complete social and moral womanhood, and childless women are often abandoned by their husbands. Women's concern with bearing and successfully rearing children may lead them to Oke Tude's weekly Women's Affairs Programme and Healing School, which offer them the means to 'destroy the yoke of barrenness'. During the Women's Affairs Programme, I heard dozens of women, and a few husbands, praying aloud to God to 'open their wombs and let their fibroids melt down in Jesus's name'. Besides barren women, quite a number of unemployed youth attend Oke Tude's services. ${ }^{26}$ At a time when a school diploma is no longer considered sufficient to secure upward social and economic mobility and the promise of a more successful life, religious movements such as Oke Tude offer disenfranchised urban youth the spiritual means - and sometimes also the material ones, in the form of business opportunities and small loans - to bridge the gap

prophesying, another feature of Pentecostal churches in Nigeria is the growing trend towards intellectualization (Marshall 2009: 179-81). In line with this trend, Nigerian Pentecostal pastors often adopt the title of 'doctor', deliver lectures, publish books, and open universities. As reflected in his name and activities, Saka - who never finished secondary school - has been influenced by this tendency.

${ }^{23}$ Similar to the strong connection between witchcraft and the Christian imagery of the Devil (Meyer 1999), Oke Tude members believe that witches and wizards conspire with jinns or Muslim spirits to block their progress in life.

${ }^{24}$ Tude resembles the $s a$ ' $i$ ritual during the hajj, when pilgrims run or rapidly walk seven times back and forth between the hills of Safa and Marwah. This is a re-enactment of Hagar's search for water before Allah revealed the water of the Zamzam well to her.

${ }^{25}$ The practice of exhibiting healed members' crutches comes from the Catholic tradition of exvotos. One sees a similar practice in T. B. Joshua's The Synagogue, Church of All Nations (SCOAN) in Lagos. Joshua's alleged healing powers have brought him international fame.

${ }^{26}$ Also Pentecostal churches appeal particularly to African women and youth, who seek to eschew patriarchal and gerontocratic hierarchies (see, for example, Van Dijk 1999; Mate 2002; Maxwell 2002). 
between their aspirations and actual possibilities. For instance, a man in his early thirties told me that 'Daddy G.O.' (General Overseer, i.e. Saka - a title that is also used in Pentecostal churches) helped him find a job and obtain a plot of land on which to build a house for his family. Although Oke Tude is not an exception, in that Pentecostal churches and Muslim organizations such as NASFAT offer similar opportunities, what makes Chrislam exceptional is that, by mixing elements from both Christianity and Islam, members believe that it is more likely that they will be 'delivered'. Several interlocutors explained to me that Chrislam allowed them to hedge their bets by 'combining the powers in Christianity and Islam', thereby doubling their chances of achieving a 'good life': that is, a life of good health and wealth. For instance, the Oke Tude imam told me that he prayed eight times a day - five times in the Muslim way and three times in the Tude way - in order to benefit from the cumulative power of prayers.

Besides the benefits, members also mentioned the 'costs' of joining Oke Tude. A young veiled woman reacted very hesitantly when I asked whether I could interview her. After many phone calls, she finally allowed me to visit her at her sister's place. She did not want me to visit her at home since her husband - a pious Muslim - does not know that she goes to Oke Tude. She attends services on Sunday morning when her husband attends NASFAT's prayer meetings. She feared that her husband and in-laws would consider her an 'unbeliever' if they knew that she attended services at Oke Tude. Because, in Islam, apostasy is considered a sin, several interlocutors from a Muslim background did not openly present themselves as Chrislamists. But because by 'running' Tude helped to cure her headaches, she took the risk of being considered an 'unbeliever'.

Even Saka - who, like Tella, was born into a Muslim family, but whose father was a famous herbalist - initially found it difficult to give up his booming business as a herbalist for a life as a Chrislamist. However, he felt he had no other choice since he had received a 'divine call' to establish his mission: 'When I was on pilgrimage to Mecca and rested near the $\mathrm{Ka}$ ' $\mathrm{aba}$, God showed me in a dream photographs of religious intolerance in Nigeria. ${ }^{27} \mathrm{He}$ assigned me to bridge the misunderstanding between Christians and Muslims ... This is how it started.' Although Saka made the pilgrimage to Mecca four times, for a long time he followed the example of his father - to the regret of his mother, who introduced herself to me as a dedicated NASFAT member - and worked as a herbalist. His vision encouraged him to stop his business in herbs, to divorce his five wives, and to establish a worship centre in a lower middle-class neighbourhood on the outskirts of Lagos. On Oke Tude's flyers, the location of the worship centre is indicated by means of the name of the closest bus stop. While one often sees doubleparked cars standing in front of Pentecostal churches on Sundays, most members travel by bus to Oke Tude. In a country where cars are seen as a status symbol, the fact that most Oke Tude members do not have a car suggests that they are from a poor background. From the outside, Oke Tude's worship centre looks like a church, but with its pillars the inside resembles a mosque. As in a mosque, Oke Tude members perform ablution and remove their shoes before entering the worship centre, and there are separate seating areas for women and men.

\footnotetext{
${ }^{27}$ The fact that Saka received photographs by divine revelation is interesting in relation to the heavy mediatization of religion in Nigeria (Larkin and Meyer 2006).
} 
Initially, Saka had wanted to register his worship centre under the name of 'Chrislamherb', a portmanteau word expressing a mixture of Christianity, Islam, and African traditional religion that believes in the power of herbs for healing purposes. However, the federal government did not approve of this 'heretic' name, which Saka then changed into Oke Tude. ${ }^{28}$ Because many people knew him as a successful herbalist, Saka soon attracted a congregation of a thousand or so followers who started worshipping in his centre in the hope of being delivered. In addition to his worship centre, Saka runs three smaller Oke Tude branches in Lagos, three in Abuja, one in Ibadan, and a house fellowship in London, but due to its particular religious constellation, the movement flourishes only in Lagos.

In addition to Tude, which takes place on an individual basis, Saka's followers engage in congregational worship. Every Sunday they assemble at 8 a.m. to participate in a Muslim prayer session (wuridi) led by an imam, followed by a Christian prayer session led by a rotating group of gifted prayer leaders, and closed with a joint service led by Saka himself. ${ }^{29}$ Before the joint service starts, the choir sings Christian and Muslim songs, as well as the Oke Tude 'anthem':

Our God, the Creator, hear us

Oh God, bless the Prophet Isa [Jesus]

And the noble Prophet [Muhammad]

Oh God, bless Samsindeen [Saka]

And the noble Prophet

Oke Tude, deliver us

Deliver us from illness

Oke Tude, deliver us.

While the singing is going on, Saka enters the stage dancing. He then begins his sermon - called a 'lecture' in Oke Tude discourse, in line with the growing trend towards intellectualization in Pentecostal churches - by quoting in both English and Yoruba verses from the Bible and Qur'an that stress the similarities between Christianity and Islam. During a service that I attended, Saka assured his followers that, irrespective of being a Christian or a Muslim, 'God would answer our prayers because we're all children of Abraham': 30

Who is a child of Abraham? A Muslim is a child of Abraham. 'Muslim' is an Arabic word that stands for 'believer' in general. As such, a Christian can be a Muslim too, because they are both believers. What Christians believe, Muslims believe and what Muslims believe, Christians believe. Do we have two different suns for Christians and Muslims? ... I have never visited a restaurant where only Muslims eat, nor have I ever shopped in a supermarket where only Christians shop. Because we are children of

\footnotetext{
${ }^{28}$ Ironically, whereas state representatives took offence at Saka's attempt to mix Christianity, Islam and Yoruba religion, they did not see a contradiction in his bringing together Christianity and Islam.

${ }^{29}$ Whereas the imam and prayer leaders were previously ordinary believers, they have been promoted to leading positions by Saka who employs them full time.

${ }^{30}$ Saka's conception of the Abrahamic religions seems to exclude Judaism. There are not many Jews in Nigeria, except for some Igbo communities with Judaic practices (Bruder 2008).
} 
Abraham, Christians and Muslims should not fight over God; God is able to fight for Himself.

Saka concluded that 'we're all the same', which - as in a Pentecostal service - was answered by the congregation clapping and shouting 'Hallelujah', with the only difference being that 'Allah Akbar' and 'Amin' (Arabic: 'So be it') were also shouted. Other services that take place on a weekly basis are the Women's Affairs Programme and Healing School mentioned above. Night vigils take place twice a month and attract a large following. Once a year, Oke Tude celebrates its anniversary, which is accompanied by festivities and the distribution of gifts among the poor. In addition, Saka holds daily counselling sessions for those seeking health and wealth.

In order to become a member of Oke Tude, one does not have to convert. A member is only expected to buy a copy of both the Bible and Qur'an, and to run Tude for seven consecutive days. To this end, new members sometimes temporarily stay in the Oke Tude guest house. Running this guest house is an additional source of income for Saka, who is also involved in selling second-hand cars and in the real-estate market. He has invested the money he earned as a herbalist in property, which he now sells to his adherents to whom he preaches that: 'To become successful in life, you must change your status from tenants into landlords.' Another of Saka's enterprises is his bookshop, where he sells his religious pamphlets, audio and visual recordings of his Sunday lectures, and bottles of anointing oil and 'Blood of Jesus' that are ascribed healing powers. Like Pentecostal and Muslim religious entrepreneurs, Saka's wish for the future is to have his own television channel: 'The whole world should know of Chrislam.'

\section{RELIGIOUS ASSEMBLAGE}

Although Tella keeps a low profile while Saka seeks publicity, there are many similarities between the two Chrislam leaders and their movements. Most importantly, they both use the term Chrislam as a concept for self-designation. Through their mixing of Christian and Muslim rituals, their aim is to deliver their followers from the evil powers that hold them trapped in bondage with Satan so that they will succeed in life. As noted above, this religious mixing has to be understood not so much in a context of religious violence - after all, Yorubaland in general and Lagos in particular are exemplars of what Laitin (1986) calls the "nonpoliticization of religion' - but rather in what Gore and Pratten (2003) call a 'culture of violence', characterized by chaos, corruption, high rates of un- and underemployment, unprecedented levels of inequality, and staggering levels of criminality. This 'culture of violence' that pervades everyday living in Lagos explains why an increasing number of the urban lower middle class, who feel frustrated by the failure of the Nigerian state to deliver welfare to its citizens, have turned to new religious movements such as Chrislam, which provide them with the spiritual as well as the pragmatic means to overcome social anxiety and economic hardship.

Larkin and Meyer explain the dynamism of reformist Christian and Muslim movements in West Africa by their ability to provide 'the networks and infrastructures that allow individuals to negotiate the material anxieties of living in uncertain economic times' (2006: 307). In a similar vein, Chrislam's popularity can be explained by its ability to negotiate the culture of insecurity that marks life in the 
'apocalyptic megacity' (Koolhaas 2001). Chrislam is not alone in providing its membership with a discourse of material and spiritual security - other religious movements also promise eternal rewards for those whose lives are marked by poverty and inequality. The difference is, as we have seen above, that Chrislam is believed to offer a more powerful discourse of hope than Christianity or Islam alone. One of Saka's religious pamphlets is entitled 'My Hope is Not Lost', encouraging readers not to lose hope in challenging times. Similarly, Tella's sermons contain moral lessons that are interpreted by his followers as 'religious pep talks', instructing them in how to combat their feelings of despair and how to become successful in life.

In this spirit of hope, most of my interlocutors rationalized their joining Chrislam in pragmatic terms, arguing that physical, spiritual and/or financial problems had led them to Ifeoluwa or Oke Tude. Many of them had been what they called 'religious shoppers', since they had attended several churches, mosques and/or shrines before turning to Chrislam. A prominent example of a 'religious shopper' is Patrick, whose search for a job and a happy life had led him to numerous Aladura, Baptist and Pentecostal churches, as well as to babalawos (traditional priest-diviners). After a failed suicide attempt, he finally ended up in Ifeoluwa. The religious 'shopping' of people like Patrick, induced by concerns about their material success and well-being in this life, challenges the conventional equation of religion with 'belief' - an equation that has been criticized by Asad (1993) as part of a post-Enlightenment Protestant legacy that needs to be located historically, but should not be taken as being universally valid. In line with the conventional conception of religion as an internally consistent belief system, anthropologists have long couched 'belief' in terms of a wholehearted personal dedication and absolute, universal truth (Ruel 1982). But rather than belief as an interior state, Chrislamists tend to privilege the performative power of religious practice that helps them negotiate their way through the insecurities and uncertainties of their situation (see also Kirsch 2004; Larkin and Meyer 2006: 287). ${ }^{31}$

Highlighting the performative power of Chrislam's rituals, a Yoruba man in his thirties explained to me that Oke Tude helped him in overcoming his past 'sinful' life by giving him a new direction:

I used to be an Area Boy, ${ }^{32}$ always engaged in street fights. My mother, a Muslim, knew someone who attended Chrislam services. Hearing about Chrislam made me curious. Upon attending Oke Tude's programmes, my life changed completely and I stopped fighting. In Nigeria Christians and Muslims are fighting. Why are we fighting when we all descend from Abraham? In Chrislam, Christians and Muslims pray together; we love each other and we find comfort in religion.

\footnotetext{
${ }^{31} \mathrm{By}$ privileging the performative aspects of religious practice over religious belief, the Chrislam leaders reassert traditional religious patterns. The predominant feature of African traditional religion is that it assigns primacy to preventing misfortune and maximizing good fortune. In this context, De Craemer et al. (1976) speak of the 'fortune-misfortune complex' in traditional religious practice. The influence of the local historical religious heritage on Chrislam deserves further study.

${ }^{32}$ 'Area Boys', or urban youth gangs, are associated with crime, '419' and violence (Momoh 2000).
} 
In line with Chrislam's pragmatic ethos, Tella's followers gain religious paraphernalia to defend themselves against attacks by evil forces that block their progress in life. In a similar spirit, Saka's Healing School teaches its participants special prayers and other techniques to heal themselves. For example, during one of the sessions, several participants complained about 'itching hands', a condition that was explained by the minister leading the Healing School as a metaphor for the situation they found themselves in: being poor, unemployed, and not being able to spend money. He guaranteed that as soon as they adhered to Oke Tude wholeheartedly - as expressed by praying vehemently, running Tude, drinking Tude water and bathing with it, and fasting - they would 'see changes in their lives' and their hands would stop itching. The prediction was responded to with eager shouts of 'Hallelujah' and 'Allah Akbar'. This example illustrates that, as in Pentecostal discourse, 'healing' - a gift of the Holy Spirit - is not only significant in its literal sense, but also as a potent metaphor for renewal and deliverance.

Chrislam's emphasis on orthopraxy (correct religious practice) rather than orthodoxy (correct belief and doctrinal conformity) prompts us to search for an approach to religion that moves beyond abstract theological paradigms and is more responsive to everyday religious practice. Because of its emphasis on orthopraxy, Chrislam offers more room for religious mixing than the orthodoxies of Christianity and Islam allow. Opposing the conventional understanding of religion as normative doctrine, Tella noted: 'I don't like dogmatic teachings.' Saka went as far as to define Chrislam in terms of a 'practical religion', offering practitioners 'tools to instant deliverance': 'People come here to fight their enemy. Their enemy is illness, barrenness, death, poverty, disillusion, frustration, failure, sorrow. We teach them how to pray to God, Moses, Jesus, and Muhammad to conquer their enemy. Prayer is the key to success.' But, as Saka stressed, success does not come automatically: 'Belief in God alone is not enough; one has to work hard for God. Faith without hard work for God is dead [worthless].' To underline the fact that pragmatism outweighs doctrine in Chrislam, one of Saka's ministers - who introduced himself to me as an alfa-pastor (alfa is the Yoruba term for a Muslim cleric) - said: 'God is not interested in our faith; to Him it doesn't matter whether we are Christians or Muslims. All He is interested in is what we do with our faith.' Indeed, as Bayat (2007: 588) points out, marginalized urban residents cannot afford to be ideological; instead, they are more likely to side with religious movements because they effectively support them in their everyday needs.

What these narratives illustrate is that Chrislam does not just promise peace and fortune in heaven; it wants to assure its membership that peace and fortune can be had on earth too. Remarkably, whereas Christian and Muslim theological doctrines focus on salvation and the afterlife, Chrislam promises a better life on earth. The general conviction among Chrislamists is that God - referred to as 'the living God' in Chrislam discourse - is immanent and active in their lives, and concerned with solving their problems (see also Hackett 1987: 237-8). Because God is believed not to be a remote entity but someone - a 'lover' in Tella's terms - with whom one can communicate through prayer, Chrislamists may influence Him through their ritual actions. This urges us to shift our attention from religion as a coherent belief system to the practicalities, complete with their incoherence, of the 'lived religion'. 
While its 'this-worldly pragmatism' (Hackett 1987: 237) explains Chrislam's popularity among its members, it also makes it vulnerable to criticism from outside. Several mainstream believers considered Chrislam a 'cult' composed of 'unbelievers'. According to them, Chrislamists are neither 'sincere' Christians nor Muslims - 'they are nothing'. Labelling a religious movement that is not aligned to mainstream Christianity or Islam a 'cult' is a popular way of abusing rival congregations in Nigeria (cf. Hackett 1989). Cultists are believed to be involved in all kinds of malevolent practices, including ritual killing and money scams, in an effort to attain 'fast wealth': that is, a form of wealth that is no longer rooted in traditional systems of kinship and patronage (Smith 2001). Similarly, many mainstream Christians and Muslims believed that Chrislamists used religion to pursue their own selfish interests and to become rich. Joining Chrislam may thus have severe social consequences for its members in that it evokes images of deviance and opportunism.

In addition to their use of Chrislam as a concept for self-designation and the performative power they ascribe to religious practice, another similarity between Tella and Saka is that they mix Christian and Muslim elements in their use of religious space, mode of worship, performance of lifecycle rituals, proselytization, organization and style. Although they are both from a Muslim background, ${ }^{33}$ their style of preaching resembles that of Pentecostal pastors, as is apparent in their focus on prayer healing and prophecy, their engagement in lively worship, and their belief in the power of the Holy Spirit. Also, in their public self-presentation they tend to adopt Pentecostal styles. Drawing upon the example of Pentecostal pastors, Tella presents himself as a 'Man of God', and, copying the leaders of the Pentecostal mega-churches' flamboyancy (cf. Meyer 2004: 448), Saka drives a Hummer. Furthermore, both Tella and Saka make use of the media in propagating their message - a message that, as in Pentecostalism, stimulates their followers' aspirations for prosperity.

The blending of elements from different religious traditions has been captured under the banner of 'syncretism' in the literature on religion in Africa. However, social scientists have increasingly doubted the usefulness of this framework to theorize religious mixture: "Syncretism" is a contentious term, often taken to imply "inauthenticity" or "contamination", the infiltration of a supposedly "pure" tradition by symbols and meanings seen as belonging to other, incompatible traditions' (Shaw and Stewart 1994: 1). At stake here is the power to identify 'true' religion and to authorize some practices as 'truthful' and others as 'false' or 'syncretic'. In particular, the underlying political agenda that motivates claims to syncretism makes it a problematic concept (MacGaffey 1983: 244-5; see also Stewart 1999). Historically, syncretism has had pejorative connotations for missiologists and theologians who used it to designate supposedly unacceptable forms of religious mixing that compromised the nominal purity of Christianity (Droogers

\footnotetext{
${ }^{33}$ During my field research in Lagos, I came across only one Chrislam leader from a nonMuslim background: Malaika, the founder of the Saint Peter's Church (New Jerusalem), has an Aladura background. During her Sunday services Malaika, who is affected by dwarfism, sits on a throne and does $d h i k r$ (remembrance of God by recalling His names), while sipping from a bottle of beer. The main part of the Sunday service is composed of singing Christian and Muslim songs, dancing, eating and drinking.
} 
1989; Leopold and Jensen 2004). Remarkably, this pejorative connotation has undergone little alteration, even among anthropologists whose mission it is to chart cultural mixing and who implicitly seem to accept that syncretism is a theological concern (Stewart 1999: 46).

Another reason why syncretism is controversial is that it is an etic rather than an emic term (Stewart 1999: 56-8). As McIntosh (2009: 185) points out, even when syncretism appears to be quite evident to the outsider, it may not be so to the insiders who insist upon the 'authenticity' of their religious practice. Indeed, syncretism may appear as anti-syncretism - defined by Shaw and Stewart as 'the antagonism to religious synthesis shown by agents concerned with the defence of religious boundaries' (1994: 7) - in the eyes of the religious practitioners themselves. ${ }^{34}$ In this spirit, what to the anthropologist may look like the combination of incommensurable religious elements into a syncretic configuration is for Chrislamists not conflictual at all. For example, during my field research I met with a university student, Sefiyat, who told me that her father is a Muslim who prays in the mosque, while her mother is a Christian who worships in Oke Tude. She herself attends the Oke Tude services during the holidays that she spends with her family in Lagos. At university she attends the Redeemed Christian Church of God. Nevertheless, she considers Oke Tude more 'effective' because she recovered from tuberculosis as a result of running Tude. Yet, when I asked her which religious affiliation she fills in on a university form, she responded: 'Muslim, of course, since my father is a Muslim.' Sefiyat's narrative challenges essentialist notions of religion that the framework of syncretism reinforces. Moreover, the relativism implied in her comments (Sefiyat remains Muslim while attending Chrislam or Redeemed Christian Church of God services) stands in marked contrast to the categorical absolutism of the anthropological conception of religion as an internally consistent belief system.

Underlining that Chrislam worshippers do not intend to harmonize Christian and Muslim beliefs and practices in a syncretic synthesis, simply because they do not necessarily recognize contradictions between these beliefs and practices, an Ifeoluwa member of long-standing responded to my question as to whether he worshipped Jesus as the son of God (as in Christianity) or as a prophet (as in Islam) that 'he is both'. Highlighting their similarity, Tella said: 'Jesus Christ is on my right-hand side, the Prophet Muhammad is on my left-hand side; they are two of my best friends.' Although my interlocutors put Christianity and Islam on the same footing as prophetic traditions, the most fundamental doctrine in Islam is tawhid, which holds that God is One. The Islamic principle that God is Unitarian differs from the Christian doctrine of the Trinity. However, Tella's first wife did not consider that these doctrines conflicted: 'God is not three but just one. Both Christians and Muslims believe in the same God and they believe that $\mathrm{He}$ is one. We aren't idol worshippers.' I had expected that Chrislamists would have problems with the notion of the Holy Spirit, because unlike the figure of Jesus this is a notion predominant in Christianity while absent in Islam, but I was proved wrong.

\footnotetext{
${ }^{34}$ An example of anti-syncretism is found in the Aladura churches; Peel (1968: 129, 133-4) criticizes studies that analyse them as syncretic churches. According to the church members, their forms of prayer healing and possession are not syncretic since they have Western Christian rather than Yoruba origins.
} 
When expressing my confusion about how the notion of the Holy Spirit had become firmly integrated within Chrislam, a female Ifeoluwa member lectured me: 'The Holy Spirit is the Holy Spirit, whether it touches a Christian or a Muslim.' Tella added: 'The Holy Spirit is not reserved to Christians - God doesn't discriminate. He revealed himself to humanity through the Holy Spirit. Muslims call him Jibril; Christians Gabriel - it's all the same.' These narratives suggest that, for Chrislamists, religion is not centrally about the truth of one religious tradition and the falsehood of others. Instead of embodying competing sets of truth claims, both Christianity and Islam are believed to represent distinct loci for achieving a state of deliverance and therefore may well be combined (see also Kirsch 2004: 707; McIntosh 2009: 183-4). ${ }^{35}$ An Oke Tude member put it strongly: 'Unlike what most people think, Chrislam is not about mixing Christianity and Islam in a new religion. We gain the good things from both.'

Because Christianity and Islam are not considered to be contradictory but rather are seen as complementary and mutually reinforcing, Chrislamists retain rather than reconcile the distinctions between the two religious traditions. For instance, female worshippers from a Muslim background often continued wearing the headscarf upon joining Chrislam. In addition to praying in the Chrislam style, several Chrislamists continued praying in either the Christian or the Muslim way at home in the hope of receiving dual blessings. In addition to fasting on Friday or when running Tude, Ifeoluwa and Oke Tude members from a Muslim background often fast during Ramadan as well. Furthermore, instead of running around the replica of the Ka'aba during Tude, several Oke Tude members told me that they were 'dreaming of going on hajj and circumambulating the Ka'aba in Mecca'. Thus Chrislamists remain, to some extent, loyal to the religious tradition in which they were born (mostly Islam), ${ }^{36}$ while making use of and interacting with another religious tradition (in most cases Christianity). This openness to religious pluralism is not only a factor in drawing people to Chrislam; it also explains why membership of Chrislam - as we have seen in the Oke Tude case - is not accompanied by any formal conversion ritual such as a baptism or sacramental communion. Rather than rejecting previous identities, as in the conversion from one religious tradition to another, Chrislamists' religious behaviour resembles what Travisano calls 'alterations': that is, 'transitions to identities which are ... permitted within the person's established universes of discourse' (1981: 244, in Kirsch 2004: 707).

From the above, it may be concluded that Chrislam's religious pluralism is not just about reconciling Christianity and Islam in a syncretic synthesis, but about drawing on both religious traditions simultaneously while marking them as distinct (see also McIntosh 2009: 188). Because of the preservation of religious differences through religious fusion, 'assemblage' - which, according to McFarlane and Anderson (2011: 162), functions as 'a name for unity across difference' - seems a more fine-grained

\footnotetext{
${ }^{35}$ Although I am referring to a different ethnographic setting than McIntosh (2009), who explores the intersection of class and ethnicity among the Kenyan Giriama whereas my article looks at the intersection between religion and ethnicity among the Nigerian Yoruba, the Chrislamists' religious practice resembles that of the Giriama. McIntosh's ethnographic analysis has helped me to develop a model that advances the study of religious plurality.

${ }^{36}$ Saka estimated that around 80 per cent of his congregation is of Muslim origin. This seems to assert the common belief that Islam is more accommodating - one could say more 'African' - than Christianity (cf. Laitin 1986: 189).
} 
analytical tool for analysing Chrislam than syncretism, which is premised on the assimilation of religious differences. Assemblage theory is derived from mechanics and has been adopted in social science scholarship under the influence of Deleuze and Guattari's $A$ Thousand Plateaus (1987). In their work, they see assemblage as the causally productive result of the intersection of two open systems. It has been Deleuze and Guattari's (1987: 503, 509, 530-1, note 39) understanding of states of temporal instability, combined with the heterogeneous as a productive property of the interaction of open systems, that has influenced its use by social scientists as an anti-structural concept that connotes emergence, heterogeneity, the decentred, the evanescent and the ephemeral (Marcus and Saka 2006: 104-5). Collier and Ong (2005) were the first anthropologists to employ assemblage theory as a lens through which to explore new socio-cultural formations emerging from globalization processes. Building on Collier and Ong, I use assemblage theory to explore new religious formations such as Chrislam (see also Peletz 2013).

Although assemblage as a conceptual frame - as pointed out by Collier and Ong (2005), Bennett (2010) and others - does not entirely fit the ethnographic case discussed here in that it describes an ad hoc congregation that is not governed by a central force, head or office, whereas in the case of Chrislam there is a charismatic leader who is very much in control, assemblage still seems more in line with the way in which Chrislamists experience their religiosity than syncretism. The notion of syncretism presupposes the distinctness of religious traditions as the default and takes mixing as a deviation. By contrast, the concept of assemblage challenges the tendency to study religious traditions uniformly and does not take religious boundaries for granted. Whereas syncretism designates an absolute category that refers to the outcome of religious blending, assemblage is emerging and rhizomatic. And while syncretism focuses on the mixing of religious elements into a new organic whole that assimilates its component parts (Baird 1991), assemblage leaves room for the juxtaposition of divergent religious elements and allows for the amalgamation to be more than simply an aggregate of its component parts. Or, in the words of Bennett, 'an assemblage is never a stolid block but an open-ended collective, a "non-totalizable” sum' (2010: 24).

To sum up, the merit of studying Chrislam as an assemblage is that the contradictions between Christianity and Islam are not reasoned away, because members are not expected to be consistent in their beliefs or committed to a single tradition of practice (see also McIntosh 2009: 189). Far from being reasoned away as in syncretism, contradictions and inconsistencies between Christianity and Islam are embraced, or even celebrated, as part of the multitude of spiritual gifts bestowed by God upon humanity - gifts that deliver Chrislamists from any hardship in their lives. The underlying idea in Chrislam's assemblage of Christianity and Islam is that to be a Christian or a Muslim alone is not enough to guarantee success in this world and in the hereafter, and therefore Chrislam worshippers adopt Christian as well as Muslim practices, appropriating the perceived powers of both.

\section{CONCLUSION}

By means of an ethnographic case study of Chrislam, I have made a plea for a conceptual reconfiguration of the Christian-Muslim encounters in Nigeria. Rather than tearing the country apart in a Christian South and a Muslim North, 
Chrislam provides its members with a powerful tool to deliberately manoeuvre between Christianity and Islam. Beginning with the religious revival in the 1970s, Lagos has produced new constellations of religion in the form of Chrislam, among others. A focus on these novel religious assemblages challenges conventional assumptions of Christianity and Islam as bounded and distinct traditions, and forces us to rethink our analytical tools for understanding religious pluralism, leaving more room for ambivalence and incoherence.

In their conceptualization of distinct religions as bounded entities constituted by a belief in God, anthropologists and other scholars of religion have long held onto contentious appellations such as syncretism, in the sense of the mingling of religious traditions that might once have been incompatible but are now rendered compatible (McIntosh 2009: 186). However, Chrislamists do not strive to harmonize Christianity and Islam, and they are not bothered by ontological contradictions between the two traditions. Since religion is for Ifeoluwa and Oke Tude members not primarily about belief but about practical concerns, the pragmatic assemblage of diverse - and often contradictory - religious elements is permitted as long as it helps them confront the contingencies of daily life in Lagos.

Studying Chrislam in terms of an assemblage fits with Larkin and Meyer's (2006) plea to go beyond the ready-made binary opposition between Christianity and Islam and to concentrate instead on their convergence. This also ties in with Lambek's (2008) call for replacing the exclusive 'either/or' binary logic that characterizes Western scholarship on religion with the pluralist logic of 'both/and' to mark local religious practice. For the Malagasy in Mayotte and north-west Madagascar studied by Lambek, religion has long been inclusive. They regularly observed that God was the same everywhere and hence it mattered little which avenue one used to approach Him. For example, a devout Malagasy Muslim told Lambek (2008: 125) that when he served as a rural policeman in a region without mosques, he simply took part in Christian observances. This resembles Chrislam's inclusive religious practice in which, instead of making absolute choices between bounded alternatives, one can be a Christian and a Muslim simultaneously.

The study of Chrislam as a religious assemblage helps us to move away from the conventional understanding of Christian-Muslim relations in terms of either religious conflict (a tendency that has gained more currency in the media since the upsurge of Boko Haram) or what scholars attempting to advance ecumenical ideas have called 'interfaith dialogue'. Although these two approaches represent opposites - the former stressing 'war' and the latter 'peace' - they suffer from the same limitation: they take religious boundaries for granted. Challenging the tendency to study Christian-Muslim interactions in terms of either conflict or cooperation, assemblage as a conceptual model helps us understand Chrislam as a heterogeneous and unstable arrangement of practices that are not reducible to a single logic. Taking such a course may eventually shift attention from a narrow analysis of 'world' religion as a coherent belief system towards a perspective that focuses on how religious practitioners actually 'live' religion in their daily lives, and on ambiguities, inconsistencies, aspirations and double standards as the constitutive moments in their lived religiosity. 


\section{ACKNOWLEDGEMENTS}

This article is based on approximately six months of ethnographic field research in Lagos, Nigeria, between 2010 and 2013. The research that took place between 2010 and 2011 was funded by the Federal Ministry of Education and Research (BMBF) in Bonn, Germany, under the auspices of the Zentrum Moderner Orient (ZMO) in Berlin. The research in 2013 was conducted as part of the project 'Global Prayers: Redemption and Liberation in the City', funded by the Forum Transregionale Studien in Berlin. An earlier version of this article was presented at the European Conference on African Studies that took place in Lisbon in 2013. I am grateful to the people who offered comments, in particular the late J. D. Y. Peel, Birgit Meyer, Brian Larkin, Benjamin Soares, Louis Brenner, Jörg Haustein and the two anonymous reviewers for Africa. My special appreciation goes to Mustapha Bello and Tobi Oshodi for their research assistance, Abubakar Momoh and his family for hosting me, my colleagues at Lagos State University - in particular Amidu Sanni, Lateef Adetona, Selome Kuponu and Danoye-Oguntale Laguda - for their helpful suggestions, and Tela Tella, Samsindeen Saka and the Chrislamists for sharing their experiences with me. All errors of fact are, of course, my own.

\section{REFERENCES}

Adesoji, A. (2010) 'The Boko Haram uprising and Islamic revivalism in Nigeria', Africa Spectrum 45 (2): 95-108.

Asad, T. (1993) Genealogies of Religion: discipline and reasons of power in Christianity and Islam. Baltimore MD: Johns Hopkins University Press.

Asad, T. (2003) Formations of the Secular: Christianity, Islam, modernity. Stanford CA: Stanford University Press.

Baird, R. (1991) Category Formation and the History of Religions. Berlin: Mouton de Gruyter.

Barber, K. (1981) 'How man makes God in West Africa: Yoruba attitudes towards the "Orisa", Africa 51 (3): 724-45.

Bayat, A. (2007) 'Radical religion and the habitus of the dispossessed: does Islamic militancy have an urban ecology?', International Journal of Urban and Regional Research 31 (3): 579-90.

Bennett, J. (2010) Vibrant Matter: a political ecology of things. Durham NC: Duke University Press.

Bruder, E. (2008) The Black Jews of Africa: history, religion, identity. Oxford: Oxford University Press.

Collier, S. J. and A. Ong (2005) 'Global assemblages, anthropological problems' in A. Ong and S. J. Collier (eds), Global Assemblages: technology, politics, and ethics as anthropological problems. Malden MA: Blackwell Publishing.

Cooper, B. M. (2006) Evangelical Christians in the Muslim Sahel. Bloomington IN: Indiana University Press.

Danfulani, U. H. D. (2005) The Sharia Issue and Christian-Muslim Relations in Contemporary Nigeria. Stockholm: Almqvist \& Wiksell International.

De Boeck, F. and M.-F. Plissart (2014) Kinshasa: tales of the invisible city. Leuven: Leuven University Press.

De Craemer, W., J. Vansina and R. Fox (1976) 'Religious movements in Central Africa: a theoretical study', Comparative Studies in Society and History 18 (4): 458-75. 
Deleuze, G. and F. Guattari (1987) A Thousand Plateaus: capitalism and schizophrenia. Minneapolis MN: University of Minnesota Press.

Droogers, A. (1989) 'Syncretism: the problem of definition, the definition of the problem' in J. G. Gort et al. (eds), Dialogue and Syncretism: an interdisciplinary approach. Amsterdam: Wm. B. Eerdmans Publishing.

Fabian, J. (1985) 'Religious pluralism: an ethnographic approach' in W. van Binsbergen and M. Schoffeleers (eds), Theoretical Explorations in African Religion. London: KPI Limited.

Falola, T. (1998) Violence in Nigeria: the crisis of religious politics and secular ideologies. Rochester NY: University of Rochester Press.

Gellner, E. (1974) Legitimation of Belief. Cambridge: Cambridge University Press.

Gore, C. and D. Pratten (2003) 'The politics of plunder: the rhetorics of order and disorder in Southern Nigeria', African Affairs 102: 211-40.

Hackett, R. I. J. (1987) 'Conclusion: religious innovation and self-determination: the continuing quest' in R. I. J. Hackett (ed.), New Religious Movements in Nigeria. Lewiston NY and Queenston: Edwin Mellen Press.

Hackett, R. I. J. (1989) Religion in Calabar: the religious life and history of a Nigerian town. Berlin and New York NY: Mouton de Gruyter.

Higazi, A. (2013) 'Les origins et la transformation de l'insurrection de Boko Haram dans le nord du Nigeria', Politique Africaine 130: 137-64.

Hock, K. (2004) The Interface between Research and Dialogue (Christian-Muslim Relations in Africa). Münster: LIT Verlag.

Janson, M. (2014) Islam, Youth, and Modernity in the Gambia: the Tablighi Jama 'at. Cambridge and New York NY: Cambridge University Press for the International African Institute.

Janson, M. (2016) “"How, for God's sake, can I be a good Muslim?”: Gambian youth in search of a moral lifestyle', Ethnography 17: 22-46.

Janson, M. (forthcoming) 'Modern love: dating the halal way in Lagos' in M. Gomez-Perez (ed.), Femmes, génération et agency en Afrique subsaharienne: vers de nouveaux defies. Paris: Karthala.

Kane, O. (2003) Muslim Modernity in Postcolonial Nigeria: a study of the Society for the Renewal of Innovation and Reinstatement of Tradition. Leiden: Brill.

Kirsch, T. (2004) 'Restaging the will to believe: religious pluralism, anti-syncretism, and the problem of belief', American Anthropologist 106 (4): 699-711.

Koolhaas, R. (2001) 'Harvard project on the city, Lagos' in S. Boeri, S. Kwinter, N. Tazi and H. U. Obrist (eds), Mutations. Barcelona: Actar.

Laitin, D. D. (1986) Hegemony and Culture: politics and religious change among the Yoruba. Chicago IL and London: University of Chicago Press.

Lambek, M. (2008) 'Provincializing God? Provocations from an anthropology of religion' in H. de Vries (ed.), Religion: beyond a concept. New York NY: Fordham University Press.

Larkin, B. (2008) Signal and Noise: media, infrastructure, and urban culture in Nigeria. Durham NC and London: Duke University Press.

Larkin, B. and B. Meyer (2006) 'Pentecostalism, Islam and culture: new religious movements in West Africa' in E. K. Akyeampong (ed.), Themes in West Africa's History. Oxford: James Currey.

Last, M. (2007) 'Muslims and Christians in Nigeria: an economy of political panic', The Round Table: The Commonwealth Journal of International Affairs 96 (392): 605-16. 
Leopold, A. M. and J. S. Jensen (2004) 'Introduction' in A. M. Leopold and J. S. Jensen (eds), Syncretism in Religion: a reader. New York NY: Routledge.

Loimeier, R. (1997) Islamic Reform and Political Change in Northern Nigeria. Evanston IL: Northwestern University Press.

Loimeier, R. (2005) 'Is there something like "Protestant Islam?", Die Welt des Islams 45 (2): 216-54.

Loimeier, R. (2007) 'Nigeria: the quest for a viable religious option' in W. F. S. Miles (ed.), Political Islam in West Africa: state-society relations transformed. Boulder CO: Lynne Rienner.

MacGaffey, W. (1983) Modern Kongo Prophets: religion in a plural society. Bloomington IN: Indiana University Press.

Marcus, G. E. and E. Saka (2006) 'Assemblage', Theory, Culture \& Society 23 (2-3): 101-9.

Marsden, M. (2005) Living Islam: Muslim religious experience in Pakistan's northwest frontier. Cambridge: Cambridge University Press.

Marshall, R. (2009) Political Spiritualities: the Pentecostal revolution in Nigeria. Chicago IL: University of Chicago Press.

Marshall-Fratani, R. (1998) 'Mediating the global and local in Nigerian Pentecostalism', Journal of Religion in Africa 28 (3): 278-315.

Mate, R. (2002) 'Wombs as God's laboratories: Pentecostal discourses of femininity in Zimbabwe', Africa 72 (4): 549-68.

Maxwell, D. (2002) 'A youth religion? Born-again Christianity in Zimbabwe and beyond' in B. Trudell, K. King, S. McGrath and P. Nugent (eds), Africa's Young Majority. Edinburgh: Centre of African Studies, Edinburgh University.

McFarlane, C. and B. Anderson (2011) 'Thinking with assemblage', Area 43 (2): $162-4$.

McIntosh, J. (2009) The Edge of Islam: power, personhood, and ethnoreligious boundaries on the Kenya coast. Durham NC: Duke University Press.

Meyer, B. (1999) Translating the Devil: religion and modernity among the Ewe in Ghana. Edinburgh: Edinburgh University Press for the International African Institute.

Meyer, B. (2004) 'Christianity in Africa: from African Independent to Pentecostal-Charismatic churches', Annual Review of Anthropology 33: 447-74.

Momoh, A. (2000) 'Youth culture and Area Boys in Lagos' in A. Jega (ed.), Identity Transformation and Identity Politics under Structural Adjustment in Nigeria. Uppsala: Nordiska Afrikainstitutet in collaboration with the Centre for Research and Documentation, Kano.

Nolte, I. (2013) 'Religion, development and politics in Nigeria' in M. Clarke (ed.), Handbook of Research on Religion and Development. Cheltenham: Edward Elgar Publishing.

Ojo, M. A. (1988) 'The contextual significance of Charismatic movements in independent Nigeria', Africa 58: 172-92.

Ottenberg, S. (1984) 'Two new religions: one analytic frame,' Cahiers d'Études Africaines 24 (96): 437-54.

Peel, J. D. Y. (1968) Aladura: a religious movement among the Yoruba. London: Oxford University Press.

Peel, J. D. Y. (2000) Religious Encounter and the Making of the Yoruba. Bloomington IN: Indiana University Press. 
Peel, J. D. Y. (2016) Christianity, Islam, and Orisa Religion: three traditions in comparison and interaction. Oakland CA: University of California Press.

Peletz, M. (2013) 'Malaysia's syariah judiciary as global assemblage: Islamization, corporatization, and other transformations in context', Comparative Studies in Society and History 55 (3): 603-33.

Ruel, M. (1982) 'Christians as believers' in J. Davis (ed.), Religious Organization and Religious Experience. London: Academic Press.

Schielke, S. and L. Debevec (2012) 'Introduction' in S. Schielke and L. Debevec (eds), Ordinary Lives and Grand Schemes: an anthropology of everyday religion. New York NY: Berghahn Books.

Shaw, R. and C. Stewart (1994) 'Introduction: problematizing syncretism' in C. Stewart and R. Shaw (eds), Syncretism/Anti-Syncretism: the politics of religious synthesis. London: Routledge.

Smith, D. (2001) 'Ritual killing, 419, and fast wealth: inequality and the popular imagination in southeastern Nigeria', American Ethnologist 28 (4): 803-26.

Smith, D. (2007) A Culture of Corruption: everyday deception and popular discontent in Nigeria. Princeton NJ: Princeton University Press.

Soares, B. F. (2006) 'Introduction: Muslim-Christian encounters in Africa' in B. F. Soares (ed.), Muslim-Christian Encounters in Africa. Leiden: Brill.

Soares, B. F. (2009) 'An Islamic movement in contemporary West Africa: NASFAT of Nigeria' in S. Ellis and I. van Kessel (eds), Movers and Shakers: social movements in Africa. Leiden: Brill.

Stewart, C. (1999) 'Syncretism and its synonyms: reflections on cultural mixture', Diacritics 29: 40-62.

Travisano, R. (1981) 'Alternation and conversion as qualitatively different transformations' in G. Stone and H. Faberman (eds), Social Psychology through Symbolic Interaction. New York NY: Wiley.

Turner, H. W. (1979) Religious Innovation in Africa: collected essays on new religious movements. Boston MA: G. K. Hall.

Ukah, A. (2013) 'Redeeming urban spaces: the ambivalences of building a Pentecostal city in Lagos, Nigeria' in J. Becker et al. (eds), Global Prayers: contemporary manifestations of the religious in the city. Berlin: Lars Müller Publishers.

Van Dijk, R. (1999) 'Pentecostalism, gerontocratic rule and democratisation in Malawi: the changing position of the young in political culture' in J. Haynes (ed.), Religion, Globalisation and Political Culture in the Third World. New York NY: St Martin's Press.

\section{ABSTRACT}

This article presents an ethnographic case study of Chrislam, a series of religious movements that fuse Christian and Muslim beliefs and practices, in its sociocultural and political-economic setting in Nigeria's former capital Lagos. In contrast to conventional approaches that study religious movements in Africa as syncretic forms of 'African Christianity' or 'African Islam', I suggest that 'syncretism' is a misleading term to describe Chrislam. In fact, Chrislam provides a rationale for scrutinizing the very concept of syncretism and offers an alternative analytical case for understanding its mode of religious pluralism. To account for the religious plurality in Chrislam, I employ assemblage theory because it 
proposes novel ways of looking at Chrislam's religious mix that are in line with the way in which its worshippers perceive their religiosity. The underlying idea in Chrislam's assemblage of Christianity and Islam is that to be a Christian or Muslim alone is not enough to guarantee success in this world and the hereafter; therefore, Chrislam worshippers participate in Christian as well as Muslim practices, appropriating the perceived powers of both.

\section{RÉSUMÉ}

Cet article présente une étude de cas ethnographique du chrislam, une série de mouvements religieux mêlant les croyances et pratiques chrétiennes et musulmanes, dans son contexte socioculturel et politico-économique à Lagos, l'ancienne capitale du Nigeria. Contrairement aux approches conventionnelles qui étudient les mouvements religieux en Afrique en tant que formes syncrétiques de « christianité africaine » ou " islam africain », l'auteur suggère que le terme " syncrétisme " est erroné pour décrire le chrislam. En réalité, le chrislam justifie que l'on examine le concept même de syncrétisme et offre un autre cas analytique possible pour comprendre son mode de pluralisme religieux. Pour expliquer la pluralité religieuse du chrislam, l'auteur a recours à la théorie des assemblages car elle propose une nouvelle manière d'étudier la mixité religieuse $\mathrm{du}$ chrislam qui correspond à la manière dont les fidèles perçoivent leur religiosité. L'idée qui sous-tend les assemblages entre la chrétienté et l'islam dans le chrislam est celle qu'être uniquement chrétien ou musulman ne suffit pas à garantir le succès dans le monde présent et dans l'au-delà ; c'est pourquoi les fidèles du chrislam suivent des pratiques chrétiennes et des pratiques musulmanes, s'appropriant ainsi les pouvoirs subjectifs des deux. 